\title{
Photosensitive porous silicon based structures
}

\author{
S. V. Svechnikov, E. B. Kaganovich, E. G. Manoilov \\ Institute of Semiconductor Physics, NAS Ukraine, 45 prospekt Nauki, Kyiv, 252028, Ukraine; E-mail: ebk@l-dif.semicond.kiev.ua
}

\begin{abstract}
We present results of electrical and photoelectrical measurements on two types of Al/porous silicon (PS)/monocrystalline silicon (c-Si)/Al sandwich structures with thin and thick PS layers obtained by stain etching. Current-voltage characteristics and photosensitivity spectra indicate that for structures with a thin PS layer the photosensitivity is determined by PS/c-Si heterojunctions (HJ), while for structures with a thick PS layer - by the PS layers themselves. The properties of PS/c-Si HJ were explained in the framework of a band diagram of the isotype HJ with opposite band bendings on the sides due to a high concentration of defect centers at the heterointerface. PS layers exhibit photoconduction with the photosensitivity maximum at $400-500 \mathrm{~nm}$. The results are compared with those obtained for the structures based on PS layers prepared by electrochemical anodization.
\end{abstract}

Keywords: porous silicon, photodiode, photoconduction, heterojunction.

Paper received 27.05.98; revised manuscript received 30.07.98; accepted for publication 28.10.98.

\section{Introduction}

Since the discovery of effective visible photoluminescence (PL) at room temperature from highly porous silicon (PS), a great deal of attention has been paid to its electronic properties because of the potential applications in Si-based optoelectronics. Studies of the photoelectric properties of PS covered such issues as transient and steady-state photoconductivity (PC) on self-supporting PS layers [1,2], PC of PS layers in metal (M)/PS/monocrystalline silicon $(\mathrm{c}-\mathrm{Si}) / \mathrm{M}$ structures [3 -5], persistent photocurrent at low $(\leq 300 \mathrm{~K})$ temperatures, i.e., a photocurrent which has a very long decay time after a short light exposure [6], photodiode properties of M/PS/c-Si/M structures [3, 5, 7-17], their photovoltaic properties $[18,19]$, photo-emf and photoinduced charge trapping in PS [19-22], and coordinate-sensitive lateral photovoltaic effect $[23,24]$.

When measuring electrical, photoelectric, and electroluminescent properties of PS, or developing lightemitting diodes and photodiodes, the heterojunction (HJ) between PS and the c-Si substrate is an essential part of the samples or device structures under investigation. However, little is known about the electronic structures of PS/c-Si HJ $[12,13,17,25]$. It has been recently shown $[12,13,17]$ that properties of highly sensitive $\mathrm{AL} / \mathrm{PS} / \mathrm{p}-\mathrm{Si} / \mathrm{Al}$ photodetectors were determined by band bending features at the PS/p-Si heterointerface.

The structure of conventional PS-based photoelectric systems is $\mathrm{M} / \mathrm{PS} / \mathrm{c}-\mathrm{Si} / \mathrm{M}$, where PS layers with the thickness ranging from several micrometers to $\sim 100 \mu \mathrm{m}$ are produced by etching c-Si electrochemically with fluoric acid. However, anodization usually results in rough PS layers having structural and optical inhomogeneities through their depth. Meanwhile, purely chemical etching is simpler and can also produce PS layers able to emit visible light similar to that of PS layers fabricated by conventional anodization. Stainetched PS layers have a thickness below $\sim 1 \mu \mathrm{m}$ and are less rough $[26,27]$.

This work is dealing with properties of $\mathrm{Al} / \mathrm{PS} / \mathrm{p}-\mathrm{Si} / \mathrm{Al}$ photosensitive structures in which PS is obtained by chemical stain etching without applying electrical bias. The purpose was to study electrical and photoelectrical properties of such structures, to compare the results with those known from literature for anodized PS layers, and to analyze them in the framework of the accepted band diagram.

\section{Experiment. Sample preparation}

Conventional photosensitive structures consisting of a series combination of a M/PS contact, PS layer, and PS/c-Si heterojunction do not allow separating the contributions of the M/PS Schottky barrier, heterojunction barrier (contact), and PS layer (bulk) to the electrical and photoelectric properties of the sample. Therefore, we formed two types of structures, with thin and thick PS layers. The contact contribution should prevail in the case of thin PS layers, of order $1 \mu \mathrm{m}$ or less, while the bulk one should be dominant for structures with thick PS layers. In both cases, samples were formed from $\mathrm{p}-\mathrm{Si}(100)$ with resistivity $10 \Omega \cdot \mathrm{cm}$. After cleaning, silicon wafers were immersed in the 1:3:5 (by volume) solution of $\mathrm{HF}: \mathrm{HNO}_{3}: \mathrm{H}_{2} \mathrm{O}$. This solution was prepared using the standard electronic grade $49 \% \mathrm{HF}$ and $70 \% \mathrm{HNO}_{3}$. The duration of etching typically ranged from 10 to $15 \mathrm{~min}$. 


\section{S. V. Svechnikov et al.: Photosensitive porous silicon based structures}
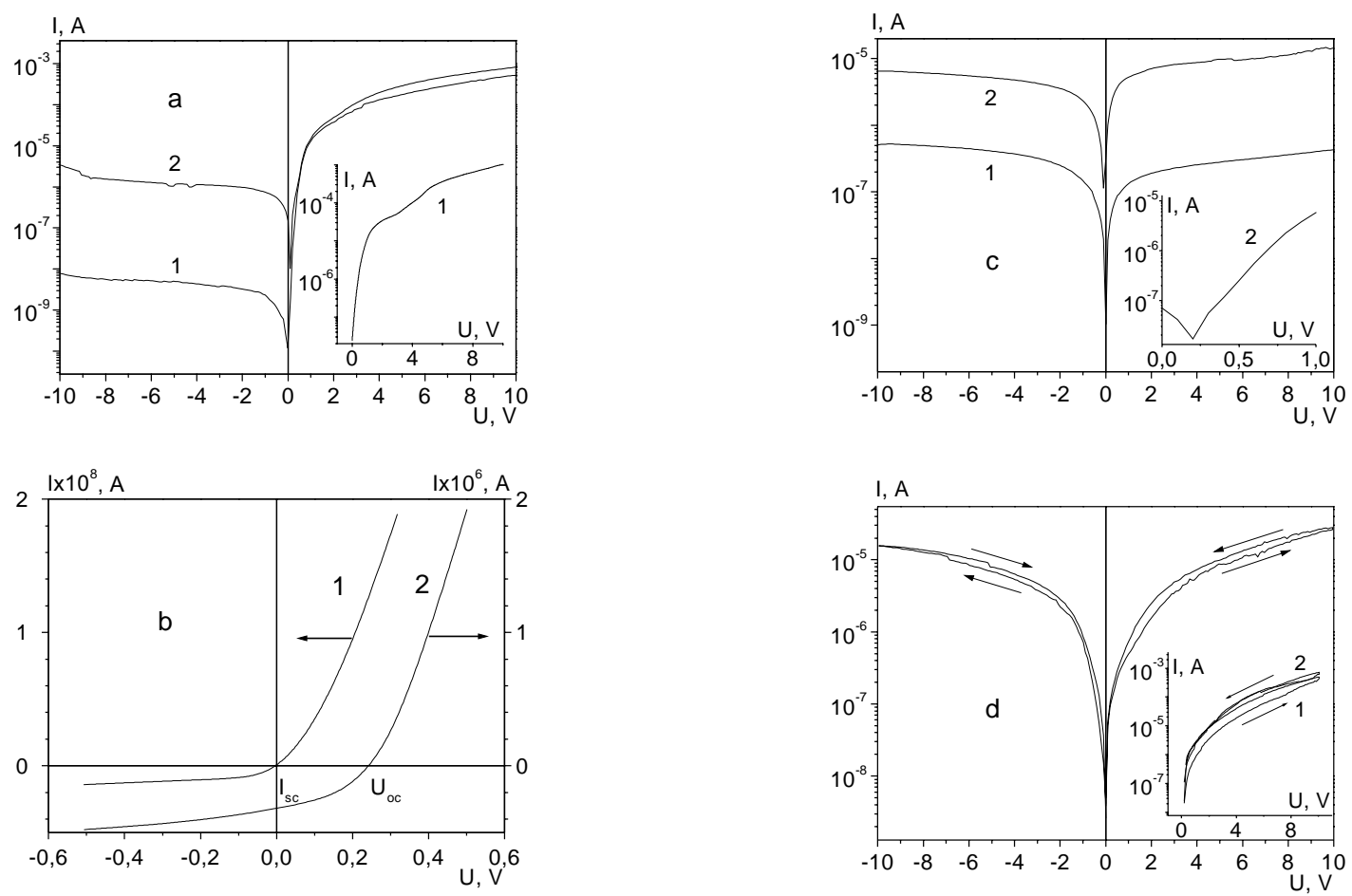

Fig. 1. I-V characteristics of Al/PS/p-Si/Al structures: static (a, b, c) and dynamic (d), with thin (a, b) and thick (c, d) PS layers, in the darkness (1) and under illumination (2). The insets show various branches of I-V curves: with a saturation section followed by a section of reversible breakdown (a), with a notch region (c), and for a structure with a thin PS layer (d).

Cross-sectional analysis reveals a nonplanar surface with a thin (less than $1 \mu \mathrm{m}$ ) porous layer of a relatively uniform thickness and a weblike morphology.

Thick porous layers were also prepared by stain etching of $\mathrm{p}$-Si wafers subjected to a preliminary laser treatment [28]. The surface of a p-Si substrate was scanned with a YAG: $\mathrm{Nd}^{3+}$ laser beam $(\lambda=1.06 \mu \mathrm{m})$ operating in the free generation mode $\left(t_{p}=0.2 \mathrm{~ms}, E=0.2 \mathrm{~J}\right)$; the scanning followed a present pattern. This technique is based on the idea that the efficiency of etching should be enhanced in the areas of p-Si where the structure is disordered due to the processes of recrystallization and defect formation stimulated by laser irradiation. This approach allowed us to decrease substantially the time required to grow on laser-treated areas PS layers of the thickness of several micrometers (1-3 min) and, thereby, to form a pattern of PS, to reduce the size of Si nanocrystallites (nc-Si), and to increase the effective area of the $\mathrm{nc}-\mathrm{Si} / \mathrm{SiO}_{\mathrm{x}} \mathrm{H}_{\mathrm{y}}$ interface, i.e., to develop an intensively disordered structure.

Under excitation with an $\mathrm{N}_{2}$ laser $\left(\lambda=0.34 \mu \mathrm{m}, t_{p}=\right.$ $=7 \mathrm{~ns}$ ), visible PL with a maximum at $650-750 \mathrm{~nm}$ was observed only from the laser treated areas both for thick and thin PS layers. PL decay spectra revealed fast short-wave and slow long-wave bands, so that photoluminescent properties of these samples seem to be same as those of PS layers prepared by electrochemical etching [28, 29].

Rear ohmic contacts were produced by $\mathrm{Al}$ evaporation followed by annealing, and front-side contacts $\left(1 \times 1 \mathrm{~mm}^{2}\right)$ by evaporation of $\mathrm{Al}, \mathrm{Au}$, and $\mathrm{In}$.
For measurements of static and dynamic current-voltage characteristics (I-V curves), voltage was increased and decreased with a step of the magnitude $0.1 \mathrm{~V}$ and different duration $(0.1 \mathrm{~s}$ and $10 \mathrm{~s})$. The time lags between the steps and measuring the current using a digital electrometer were $200 \mathrm{~ns}$. The transient current caused by applying a voltage step to a capacitor decayed in $10 \mathrm{~s}$. The spectral response of the structures was measured in the wavelength range from 400 to $1000 \mathrm{~nm}$ with a standard photodetector circuit and a bias of several volts. In addition, the spectral response was measured in the open circuit mode.

\section{Results and discussion}

For the structures with thin PS layers, I-V curves measured in the darkness exhibit a typical rectifying behavior (fig. 1(a), curve 1). The rectification ratio at a bias of several volts reaches the value of $\sim 10^{5}$. The positive direction of voltage in this figure (forward current) corresponds to a positive bias applied to $\mathrm{p}-\mathrm{Si}$. The reverse branch displays current saturation, which is always clearly pronounced. Analysis of the forward current gives the value of the series resistance of PS amounting to several kiloohms, and the ideality factor at small bias of approximately 2 to 3 . For some samples, the forward branch shows a sign of a reversible breakdown of the heterojunction: a small saturation segment of the I-V curve is followed by a segment where the current increases (fig. 1(a), inset). 


\section{S. V. Svechnikov et al.: Photosensitive porous silicon based structures}

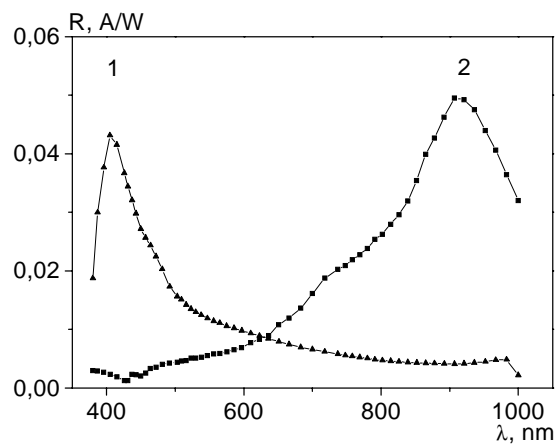

Fig. 2. Photosensitivity spectra of $\mathrm{Al} / \mathrm{PS} / \mathrm{p}-\mathrm{Si} / \mathrm{Al}$ structures with thick (1) and thin (2) PS layers.

Under illumination, the I-V curve (fig. 1(a), curve 2) is typical for a photodiode. At a reverse bias of several volts, the ratio of current measured under illumination and in the darkness is one to two orders. The photocurrent increases with reverse bias very slowly. The open circuit voltage $\left(V_{\mathrm{oc}}\right)$ is about 0.25 to $0.3 \mathrm{~V}$, and the sign of $V_{\text {oc }}$ corresponds to the depletion band bending of p-Si (fig. $1(\mathrm{~b})$, curve 2 ).

The forward branches of the dynamic I-V curves in the dark and under illumination display hysteresis loops (fig. 1(d), inset). This indicates the presence of slow traps for holes. The reverse branches do not show any hysteresis.

The spectral dependence of photosensitivity peaks at $900 \mathrm{~nm}$ (fig. 2, curve 2), and has the same shape as that for Si photodiodes. This indicates that the light absorption that takes place in $\mathrm{p}-\mathrm{Si}$ is dominant. The magnitude of photosensitivity in the best samples is as high as $\sim 0.1 \mathrm{~A} / \mathrm{W}$. With a front-side Al contact of good transparency, the quantum yield in the vicinity of the photosensitivity maximum is high and close to unity.

The photoresponse spectrum curve measured in the open circuit mode displays a change of the photoresponse sign in the short-wave and long-wave regions (fig. 3).

For the structures with thick PS layers of low conductivity, the I-V curves measured in the darkness are symmetrical and nonlinear. The ratio of current measured under illumination $\left(10^{-2} \mathrm{~W} / \mathrm{cm}^{2}\right)$ and in the darkness at a bias of several volts is one or two orders of magnitude, and does not depend on the polarity of the voltage applied. Some sections of the I-V curves measured under illumination display notches indicating the presence of a built-in electric field (fig. 1(c), inset). Hysteresis loops demonstrating the capture of holes on slow traps are seen on the forward and reverse branches of the I-V curves (fig. 1(d)). The photosensitivity spectrum measured by us has a maximum in the short-wave range of $400-500 \mathrm{~nm}$ (fig. 2, curve 1).

In this work, the results are analyzed in the framework of a model which does not take into consideration the role of the Al/PS Schottky barrier. Previous I-V measurements for the structures with different metal films $(\mathrm{Al}, \mathrm{Cu}, \mathrm{Au})$ evaporated on thin and thick PS did not reveal any dependence of barrier parameters on the specific metal. A similar behavior of the M/PS interface was observed in [16], where

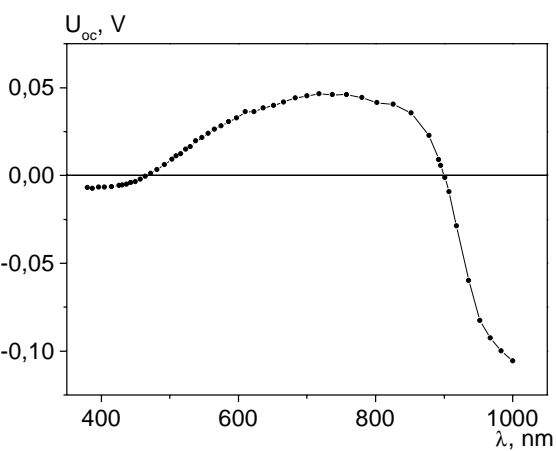

Fig. 3. Photoresponse spectrum of an $\mathrm{Al} / \mathrm{PS} / \mathrm{p}-\mathrm{Si} / \mathrm{Al}$ structure with a thin PS layer measured in the open-circuit mode.

only the series resistance depended on the particular metal evaporated $(\mathrm{Ca}, \mathrm{Mg}, \mathrm{Sb}$, and $\mathrm{Au})$. Analysis of the $\mathrm{I}-\mathrm{V}$ and capacitance-voltage curves [17] shows that the band bending near the M/PS interface can be neglected. The authors of $[12,13]$ were also dealing with photosensitive $\mathrm{Al} / \mathrm{PS} / \mathrm{c}-\mathrm{Si} /$ $\mathrm{Al}$ structures, and came to the conclusion that the $\mathrm{Al} / \mathrm{PS}$ contact can be considered as a weakly rectifying one.

The above-mentioned results obtained for the structures with a thin PS layer can be explained in the framework of the energy band diagram for the isotype heterojunction between a wide-band PS (2 to $3 \mathrm{eV})$ and c-Si $(1.1 \mathrm{eV})$ with close charge carrier concentrations, taking into account the interface states (fig. 4) [30,31]. This kind of a diagram formed by two rear-to-rear connected Schottky diodes was proposed in [12] for sensitivity analysis of photodiode structures based on $\mathrm{p}-\mathrm{PS} / \mathrm{p}$-Si heterojunctions. Indeed, saturation of I-V curves in both directions and different polarity of photoresponses are inherent to such a model, and are observed in our experiments as well.

When the energy of quanta of the incident light exceeds the band gap of $\mathrm{p}-\mathrm{Si}$, but is smaller than that of PS, light is absorbed in $\mathrm{p}-\mathrm{Si}$, and the sign of photoresponse is determined by the charge of holes moving from the $\mathrm{HJ}$ interface to the ohmic contact (positive photoresponse, see fig. 3) in full accordance with a depletion-type band bending. When the energy of quanta of the incident light reaches the band gap of porous silicon, this gives rise to a photogeneration of holes in PS. Negative photoresponse in the short-wave region associated with the movement of these photoholes from the HJ interface into the PS depth agrees with the opposite sign of the Schottky barrier from the PS side. Negative photoresponse in the long-wave spectral region can be attributed to photoexcitation of charge carriers from the surface electronic states (SES) associated with interface traps or to optical transitions from the valence band of porous silicon to the conductance band of c-Si.

Previously [13], a similar hysteresis and photoresponses of different polarities were observed for $\mathrm{Al} / \mathrm{PS} / \mathrm{p}-\mathrm{Si} / \mathrm{Al}$ structures. However, for these structures the reverse current increased linearly with bias, and the forward current could be extrapolated by an exponential function. The authors of [13] interpreted these results in the framework of a model of an 


\section{S. V. Svechnikov et al.: Photosensitive porous silicon based structures}

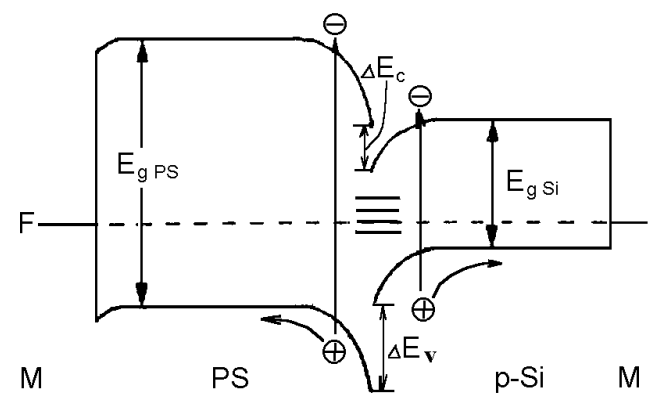

Fig. 4. Schematic band diagram of an $\mathrm{Al} / \mathrm{PS} / \mathrm{p}-\mathrm{Si} / \mathrm{Al}$ structure with a thin PS layer [12, 25].

isotype HJ whose energy band diagram has a small peak and a hollow. Measurements of the photoinduced charge trapped in PS [20] revealed the photo-emf component associated with the depletion region in $\mathrm{p}-\mathrm{Si}$ at the PS interface and the presence of slow states at the porous surface.

The results obtained for the structures with a thick PS layer indicate that their photosensitivity is determined by the photoconductivity of porous silicon. Taking into account the photoluminescent properties of the layers, these results allow to introduce an energy band diagram that includes quantum-size c-Si nanocrystallites with local states in the quantum well and $\mathrm{SiO}_{\mathrm{x}} \mathrm{H}_{\mathrm{y}}$ barrier layers in which the composition and height of potential barriers change depending on the conditions of PS formation. Absorption of light is determined by optical transitions between the local states in c-Si nanocrystallites and between them and delocalized states in the barrier layers.

Only drifting charge carriers can contribute to the photoconductivity, but not those taking part in paired radiative recombination and in radiative recombination via the surface states of the crystallites. That is why the quantum yield of photoconductivity is small. Therefore, the conditions needed for high intensities of the photoluminescence and photoconductivity are opposite. To increase the intensity of PL, it should be difficult for charge carriers to escape from Si nanocrystallites, while for high photoconductivity, on the contrary, the potential barriers limiting the transport of charge carriers should be lowered. Since the mobilities of charge carriers in PS are small (they do not exceed $10^{-2}$ to $10^{-3} \mathrm{~cm}^{2} / \mathrm{V} \cdot \mathrm{s}[32]$ ), and the product of drift mobility by charge carrier lifetime is approximately equal to $10^{-10} \mathrm{~cm}^{2} / \mathrm{V}[1]$, then even in strong electric fields the drift length of charge carriers does not reach one micrometer. Therefore, a thin layer of porous silicon can be used for increasing the collection factor of charge carriers.

The key questions defining the photoconductivity of porous silicon are as follows: what is the medium and what is the mechanism for charge carrier transport. Since PS is nanocomposite, and its matrix consisting of porous hydrogenated silicon oxide contains quantum wires and quantum dots of $\mathrm{c}-\mathrm{Si}$, then charge carrier tunneling through barriers between silicon nanocrystallites is possible, as well as transport of carriers injected from silicon nanocrystallites through the region of the interface and barrier layers. So, the localization and the mechanisms of transport can be distinguished not only by the dependence on the layer preparation conditions and their microstructure, respectively, but also by the conditions of photoconductivity measurements: excitation level, temperature, and electric field. Currently, studies of the transport properties of photoconductive PS layers are only at the initial stage.

In summary, I-V and spectral photoresponse characteristics of $\mathrm{Al} / \mathrm{PS} / \mathrm{c}-\mathrm{Si} / \mathrm{Al}$ structures were measured. Unlike to the conventional technique, the PS layers were prepared by chemical etching, without applying the electric field. It was shown that in such structures it is possible to achieve in a more simple way not only photoluminescent, but also electrical and photoelectrical properties similar to those of the structures based on PS formed by anodization. Thin (less than one micrometer) PS layers prepared by chemical etching can be made more homogeneous, with a smooth surface, and lower leakage current. It is found that the photodiode properties of these structures are determined by the isotype p-PS/p-Si heterojunction, taking into account the effect of localized states at the interface. The photosensitivity of structures in which the properties of M/PS and PS/cSi heterojunction barriers are not displayed is determined by the photoconductivity of porous silicon, with the maximum of its spectral dependence near 400 to $500 \mathrm{~nm}$. Hysteresis loops seen on the I-V curves indicate the presence of slow traps in the PS layer.

\section{References}

1. O. Klima, P. Hlinomaz, A. Hospodkova, J. Oswald, and J. Kocka, J. of Non-Cryst. Solids, 961, pp. 164 - 166 (1993).

2. P. Hlimonaz, O. Klima, A. Hospodkova, E. Hulicius, J. Oswald, E. Sipek, and J. Kocka, Appl. Phys. Lett., 64, p. 3118 (1994).

3. T. Ozaki, M. Araki, S. Yoshimura, H. Koyama, N. Koshida, J. Appl. Phys., 76, p. 1986 (1994).

4. M. J. Heben, Y. S. Tsuo, MRS Symp. Proc., p. 283 (1993).

5. A. Dafinei, G. Cracium, C. Flueraru, C. Sargentis, and E. Niculescu, CAS 97 Proc. of the 1997 Int. Semicond. Conf., (Sinaia, Romania, 1997), p. 189.

6. W. H. Lee, H. Lee, and C. Lee, J. of Non-Cryst. Sol., 965, pp. $164-$ 166 (1993).

7. J. P. Zheng, K. L. Jiao, W. P. Shen, W. A. Anderson, H. S. Kwok, Appl. Phys. Lett., 61, p. 459 (1992).

8. H. Shi, Y. Zheng, Y. Wang, and R. Yuan, Appl. Phys. Lett., 63, p. 770 (1993).

9. L. V. Belyakov, D. N. Goryachev, O. M. Streseli, I. D. Yaroshetskii, Semiconductors, 27, p. 1371 (1993).

10. L. Z. Yu, C. R. Wie, Sensors and Actuators A, 39, p. 253 (1993).

11. C. Tsai, K.- H. Li, J.C. Campbell, and A. Tasch, Appl. Phys. Lett., 62, p. 2818 (1993).

12. L. A. Balagurov, D. G. Yarkin, G. A. Petrovicheva, E. A. Petrova, A. F. Orlov, and S. Ya. Andryushin, J. Appl. Phys., 82, p. 4647 (1997).

13. A. N. Laptev, A. V. Prokaznikov, N. A. Rud', Pisma v J. Techn. Phys., 23, p. 59 (1997).

14. E. V. Astrova, A. A. Lebedev, A. D. Remenyuk, V. Yu. Rud', Yu. V. Rud', Semiconductors, 31, p. 159 (1997).

15. V. Yu. Rud', Yu. V. Rud', Semiconductors, 31, p. 245 (1997).

16. N. J. Pulsford, G. L. J. A. Rikken, Y. A. R. R. Kessener, E. J. Lous, and A. H. J. Venhuizen, J. of Lumin., 57, p. 181 (1993).

17. C. Peng, K. D. Hirschman, and P. M. Fauchet, J. Appl. Phys., 80, p. 295 (1996). 


\section{S. V. Svechnikov et al.: Photosensitive porous silicon based structures}

18. G. Smestad, M. Kunst, C. Vial, Sol. Energy Mat. and Sol. Cells., 26, p. 277 (1992).

19. Yu. A. Vashptanov, Pisma v J. Techn. Phys., 23, p. 77 (1997).

20. A. B. Matveeva, E. A. Konstantinova, V. Yu. Timoshenko, P. K. Kashkarov, Semiconductors, 29, p. 2180 (1995).

21. P. K. Kashkarov, E. A. Konstantinova, A. V. Petrov, A. V. Petruchin, V. Yu. Timoshenko, Surface. Physics, chemistry, mechanics, 6, p. 75 (1994).

22. A. V. Petrov, A. V. Petruchin, Semiconductors, 28, p. 82 (1994).

23. C. C. Yeh., K. Y. J. Hsu, L. K. Samanta, P. P. Chen, and H. L. Hwang, Appl. Phys. Lett., 62, p. 1617 (1993).

24. D. W. Boeringer, R. Tsu, Appl. Phys. Lett., 65, p. 2332 (1994).

25. P. H. Hao, X. Y. Hou, F. L. Zhang, and Xun Wang, Appl. Phys. Lett., 64, p. 3602 (1994).

26. R. W. Fathauer, T. George, A. Ksendzov, and R. P. Vasquez, Appl. Phys. Lett., 60, p. 995 (1992).
27. J. Sarathy, S. Shih, Kim Jung, C. Tsai, K.-H. Li, D.-L. Kwong, J. C. Campbell, Shueh-Li Yau, and A. J. Bard, Appl. Phys. Lett., 60, p. 1532 (1992)

28. S. V. Svechnikov, L. L. Fedorenko, E. B. Kaganovich, A. D. Sardarly, S. P. Dikii, S. V. Baranetz, J. Ukrain. Physics, 39, p. 704 (1994).

29. L. L. Fedorenko, A. D. Sardarly, E. B. Kaganovich, S. V. Svechnikov, S. P. Dikii, S. V. Baranetz, Semiconductors, 31, p. 6 (1997).

30. A. G. Milnes and D. L. Feucht, Heterojunctions and Metal-Semiconductors Junctions, Academic, New York (1972).

31. B. L. Sharma and R. K. Purohit, Semiconductor Heterojunctions, Pergamon, Oxford (1974).

32. L. L. Kazakova, A. A. Lebedev, E. A. Lebedev, Smiconductors, 31, p. 7 (1997).

\section{ФОТОЧУТЛИВІ СТРУКТУРИ НА БАЗІ ПОРИСТОГО КРЕМНІЮ}

\section{С. В. Свєчніков, Е. Б. Каганович, Е. Г. Манойлов}

Інститут фізики напівпровідників НАН Украӥни

Резюме. Представлені результати електричних та фотоелектричних вимірювань двох типів Аl/пористий кремній (ПК)/ монокристалічний кремній (c-Si)/Al сендвич структур с тонкими та товстими шарами ПК, що одержані хімічним забарвлюючим травленням. Вольт-амперні характеристики та спектри фотовідгуків свідчать про те, що фоточутливість структур з тонкими шарами ПК переважно визначається гетеропереходом (ГП) ПК/c-Si, а з товстими - ПК шарами. Властивості ГП з’ясовані в рамках зонної діаграми ізотипного ГП з протилежними напрямками вигину зон по обидва боки переходу завдяки високій концентрації дефектів на межі розподілу. ПК шари - фоточутливі, 3 максимумом чутливості біля 400-500 нм. Результати порівнюються з такими для структур на основі шарів ПК, що одержані електрохімічним травленням.

\section{ФОТОЧУВСТВИТЕЛЬНЫЕ СТРУКТУРЫ НА ОСНОВЕ ПОРИСТОГО КРЕМНИЯ}

\section{С. В. Свечников, Э. Б. Каганович, Э. Г. Манойлов}

\section{Институт физики полупроводников НАН Украины}

Резюме. Представлены результаты электрических и фотоэлектрических измерений двух типов $\mathrm{Al} /$ пористый кремний (ПК)/ монокристаллический кремний (c-Si)/Al сэндвич структур с тонкими и толстыми слоями ПК, полученными химическим окрашивающим травлением. Вольт-амперные характеристики и спектры фотооткликов свидетельствуют, что фоточувствительность структур с тонкими слоями ПК определяется гетеропереходом (ГП) ПК/c-Si, а с толстыми - ПК слоями. Свойства ГП объяснены в рамках зонной диаграммы изотипного ГП с противоположными направлениями изгибов зон по обе стороны перехода из-за высокой концентрации дефектов на гетерогранице. ПК слои - фотопроводящие с максимумом фоточувствительности при 400-500 нм. Результаты сравниваются с таковыми для структур на основе слоев ПК, полученных электрохимическим травлением. 